\title{
HYPHOMYCETES FROM SOIL OF AN AREA AFFECTED BY COPPER MINING ACTIVITIES IN THE STATE OF BAHIA, BRAZIL
}

\author{
Isabella P.M. Wanderley Costa; Maria Auxiliadora Q. Cavalcanti*; Maria José S. Fernandes; Débora M.M. Lima
}

Universidade Federal de Pernambuco, Centro de Ciências Biológicas, Departamento de Micologia, Recife, Pernambuco, Brasil

Submitted: May 03, 2005; Approved: July 17, 2006

\begin{abstract}
With the aim of observing the impact produced by copper-mining activities on soil fungi, samples were collected from an area at the Caraíba Mining, in the State of Bahia, Brazil. This area was divided in six subareas: one had native vegetation and was used as control, while the others varied according to degrees of impact. The samples, collected during the dry and the rainy seasons, were submitted to serial dilutions and placed on Petri dishes with Sabouraud medium plus antibiotic. Sixty five species and 16 genera of Hyphomycetes were identified: Acremonium, Acrophialophora, Aspergillus, Cladosporium, Chrysosporium, Curvularia, Fusarium, Humicola, Malbranchea, Myrothecium, Paecilomyces, Penicillium, Scolecobasidium, Staphylotrichum, Stilbella and Trichoderma. Acrophialophora levis, Crhysosporium merdarium, Curvularia verruculosa, Malbranchea chrysosporoidea, Penicillium adametzii, Staphylotrichum coccosporum and Stilbella sebacea were isolated for the first time in Brazil.
\end{abstract}

Key words: ecology, impacted area, mycology, soil fungi

\section{INTRODUCTION}

The soil is one of the most important habitats for microorganisms and filamentous fungi and yeasts are the major contributors to soil biomass. Forming a group of organotrophic organisms responsible primarily for the decomposition of organic compounds (18), the fungi participate actively on processes related to biodeterioration and biodegradation $(2,11)$, contributing for nutrient cycling and, consequently, for the maintenance of ecosystems.

Several groups of fungi can be isolated from soil, such as Zygomycetes, Ascomycetes and anamorphic fungi $(4,9)$. The Hyphomycetes can be distinguished because they have a broad geographical distribution and can be found in several substrates, including soil $(1,5)$.

However, there are few studies about the isolation of fungi from soil in areas affected by heavy metals. Silva et al. (22) regarded the potential of infectivity of arbuscular mycorrhizal fungi (AMF) in soil of Caraíba Mining, Bahia, Brazil; Fassatiová
(16), isolated micromycetes in uranium mining in Czechoslovakia; Nordgren et al. (17), isolated microfungi from soil in an area polluted by heavy metal in Sweden and Arnebrant et al. (3), informed the copper tolerance by microfungi isolated from polluted and unpolluted forest soil in Sweden.

This research represents the first survey of the Hyphomycetes isolated from soil of a copper mining area in Brazil, aiming to evaluate the effects of site and season on fungal colonization.

\section{MATERIALS AND METHODS}

\section{Study area}

The Caraíba Mining is located at Pilar, Municipality of Jaguararí, Bahia State, Brazil (9 $9^{\circ} 51^{\prime} 43^{\prime \prime} \mathrm{S}$ and $39^{\circ} 53^{\prime} 50^{\prime \prime} \mathrm{W}$ ) is the biggest mining of northeastern Brazil where copper is extracted. The annual precipitation is $400 \mathrm{~mm}$ and the rainy season is from November to April, with an average temperature of $25^{\circ} \mathrm{C}$. The vegetation is characterized by typical xerophytic vegetation, *Corresponding Author. Mailing address: Av. Boa Viagem, 3376, apto.92, Boa Viagem. 51020-001, Recife, PE, Brasil. Tel.: (+5581) 3466-4235.
E-mail: xiliamac@terra.com.br 
called caatinga and the soil is of two types: sand-clay and clay. The climate is classified as tropical semi-arid.

The studied area was divided into six sub-areas: I- A site that received the waste product, formed by the rock powder from which the metal was extracted. In this place there were no plants except during the rainy season. II- A place around the industrial area, characterized by absence of native plant species and the presence of many pioneer species, which dominate the area after the removal of the native vegetation. III- Low-grade deposits, some forming piles as high as $20 \mathrm{~m}$. Few pioneer plants have been found in this sub-area. IV- A preserved caatinga, considered as the control sub-area, with many native species. $\mathrm{V}$ - interface between the caatinga and the waste product area, where some plants were dry and defoliated. VI- A site for extracting top soil for purpose of land fill (22).

\section{Soil sampling}

Soil samples were collected from the $5-20 \mathrm{~cm}$ depth, during the dry (August/1998) and rainy (February/1999) seasons from six sub-areas, five affected by mining and one with native vegetation of "caatinga" preserved. In each sub-area seven soil samples were collected to make a compound (Fig. 1). These samples were taken preferentially from the rhizosphere of plants chosen at random. The analysis of the soil was done by the Soil Laboratory of EMBRAPA/CPATSA(15) (Table 1).

\section{Isolation and identification of fungi}

Soil samples were diluted and plated, using Clark's (7) method, modified as follows: $25 \mathrm{~g}$ of each sample was diluted in $225 \mathrm{~mL}$ of distilled sterilized water. From this suspension, $10 \mathrm{~mL}$ were added to $990 \mathrm{~mL}$ of water and from this, $1 \mathrm{~mL}$ was spread in Petri dishes, in triplicate, containing Sabouraud Agar plus chloramphenicol $(100 \mathrm{mg} / \mathrm{L})$ and maintained at room temperature $\left(28^{\circ} \mathrm{C} \pm 2^{\circ} \mathrm{C}\right)$ for 72 hours. Inoculum of the formed colonies were transferred to Czapek Agar (Cz), Potato Dextrose Agar (PDA) and Malte extract Agar for identification, using current taxonomical literature $(6,9,12,13,19,20)$.

\section{Statistical analysis}

The Tukey test $(\sqrt{ } \mathrm{x}+1)$ was used to evaluate differences between numbers of colonies isolated from each sub-area during the dry and rainy seasons (14). The grouping test of ScottKnot (21) was utilized to evaluate which species were more predominant in this research. The data were evaluated to a 5\% of significance level.

\section{RESULTS}

Sixteen genera and 65 species of Hyphomycetes were isolated out of 1293 fungal colony forming units (CFU). Aspergillus was the genus with the highest number of species (25 species), followed by Penicillium (18), Acremonium (4),

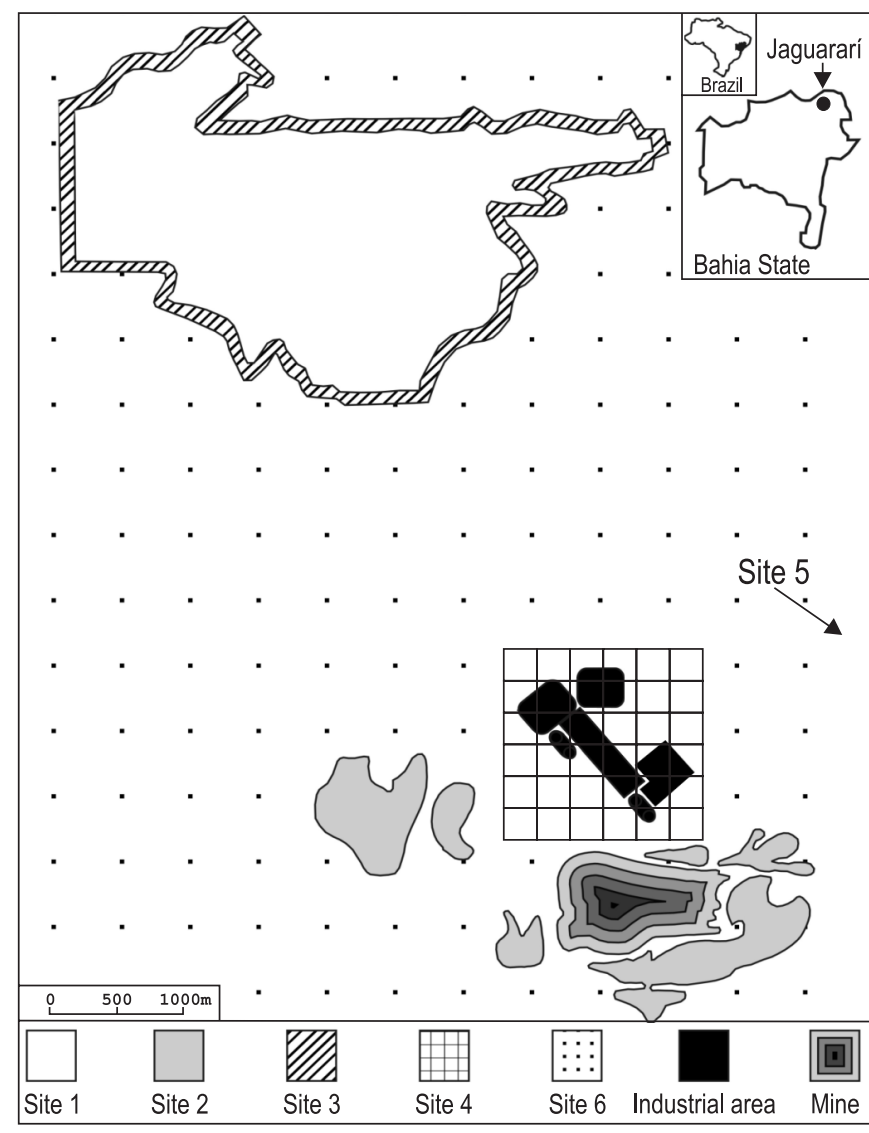

Figure 1. Collecting sites in the Caraíba copper mine, Jaguararí, Bahia State (upper right inset). 1 Site that receives the waste product, 2 site that receives the lowgrade deposits, 3 the interface between the caatinga and waste product area, 4 the surrounding of industrial area, 5 the site for extracting topsoil for the purpose of land filling, 6 preserved caatinga.

Paecilomyces (3), Fusarium, Trichoderma and Cladosporium (2). Acrophialophora, Chrysosporium, Curvularia, Humicola, Malbranchea, Myrothecium, Scolecobasidium, Staphylotrichum and Stilbella had one species each (Table 2).

Of the six sub-areas studied, sub-area IV (control) had the highest number of species (33), followed by sub-areas II (27), III (24), VI (21), V (12) and I (10). Sub-area IV also presented the highest number of CFU (399), followed by sub-areas II (296), III (240), VI (206), I (112) and V (40).

Aspergillus terreus was isolated in all sub-areas during both seasons, with the exception of the rainy season in sub-area I. Aspergillus fumigatus and Fusarium solani were isolated from soils of almost all sub-areas, with exception of sub-areas $\mathrm{V}$ and I, respectively. Paecilomyces lilacinus had the highest number of CFU (119), followed by Penicillium adametzii (106), P. fellutanum (97) and Acremonium roseolum (90). 
I.P.M.W. Costa et al.

Table 1. Chemistry and granulometric analysis from soil of the six sub-areas from Caraíba Mining, Jaguararí, Bahia. P*-available P by Mehlich method.

\begin{tabular}{|c|c|c|c|c|c|c|c|c|c|c|c|c|c|}
\hline \multirow{2}{*}{ Sub-areas } & \multirow{2}{*}{$\mathrm{P}^{*}$} & $\mathrm{Cu}$ & $\mathrm{Mn}$ & $\mathrm{Zn}$ & $\mathrm{Fe}$ & $\mathrm{K}$ & $\mathrm{Mg}$ & $\mathrm{Ca}$ & $\mathrm{Al}$ & \multirow{2}{*}{$\begin{array}{c}\mathrm{pH}\left(\mathrm{H}_{2} \mathrm{O}\right) \\
1: 2.5 \\
\end{array}$} & \multicolumn{3}{|c|}{ Granulometria $\%$} \\
\hline & & \multicolumn{4}{|c|}{$\mathrm{cmol}^{\mathrm{dm}}{ }^{-3}$} & \multicolumn{4}{|c|}{ meq. $100 \mathrm{~g}^{-1}$ of soil } & & Sand & Silt & Clay \\
\hline I & 266 & 433.4 & 53.4 & 5.7 & 434.4 & 0.06 & 1.4 & 5.2 & 0.00 & 8.2 & 93 & 3 & 4 \\
\hline II & 44 & 86.2 & 33.4 & 2.0 & 65.9 & 0.25 & 5.9 & 10.5 & 0.04 & 6.9 & 60 & 24 & 16 \\
\hline III & 167 & 606.7 & 44.0 & 5.2 & 168.1 & 0.27 & 5.9 & 7.1 & 0.01 & 7.3 & 69 & 21 & 10 \\
\hline IV & 141 & 2.7 & 46.4 & 2.2 & 33.6 & 0.30 & 3.7 & 8.0 & 0.05 & 6.2 & 62 & 24 & 14 \\
\hline $\mathrm{V}$ & 179 & 445.4 & 47.8 & 5.0 & 337.1 & 0.61 & 1.8 & 6.0 & 0.00 & 7.8 & 61 & 35 & 4 \\
\hline VI & 95 & 30.4 & 48.6 & 1.6 & 52.4 & 0.22 & 5.4 & 9.4 & 0.17 & 7.1 & 65 & 19 & 16 \\
\hline
\end{tabular}

Table 2. Total (T) of fungal colony forming units (CFU) of Hyphomycetes species isolated from soil of Caraíba Mining in six subareas (I, II, III, IV, V and VI), during the dry (D) and rainy (R) seasons.

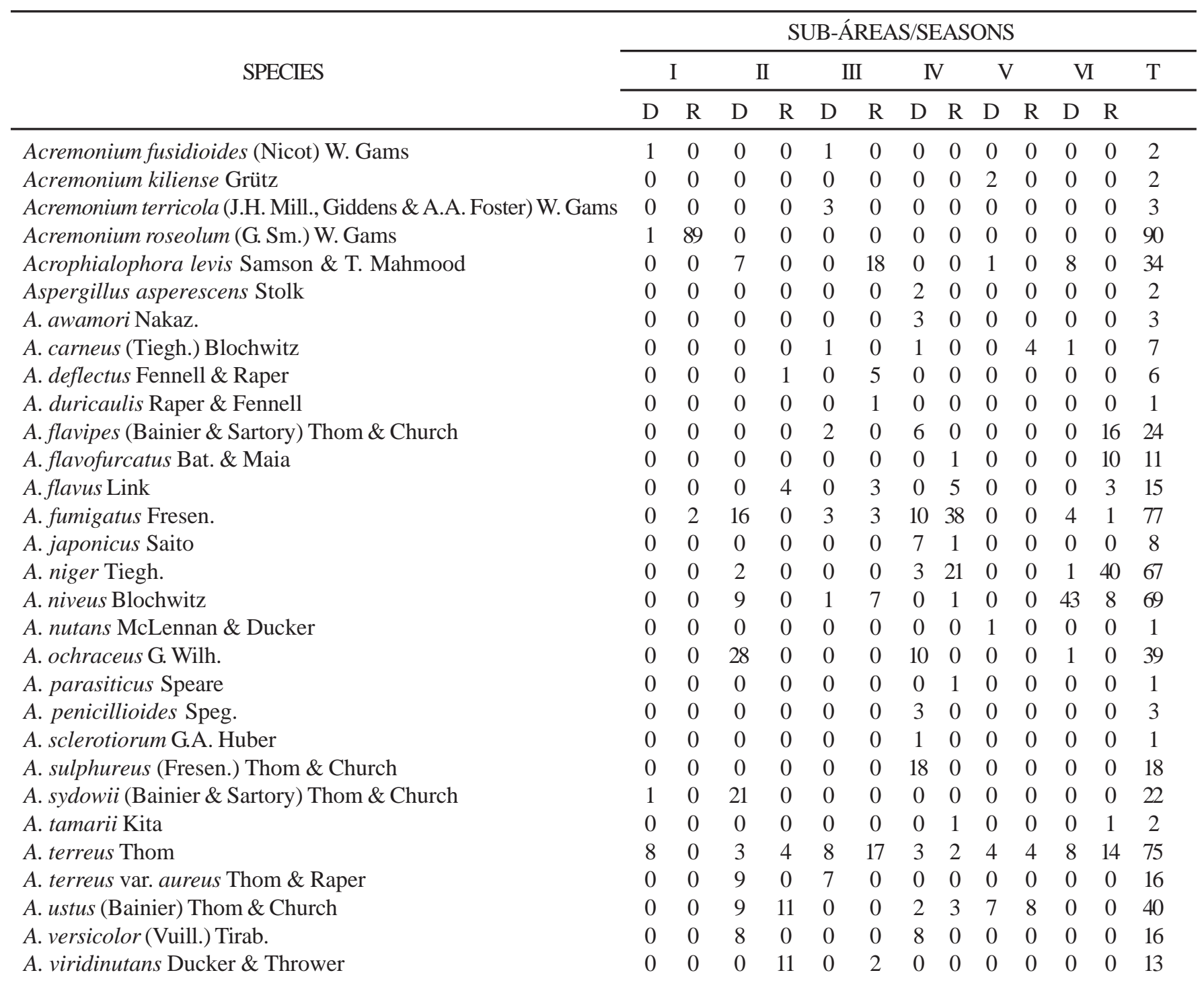


Cladosporium cladosporioides (Fresen.) G.A. de Vries

Cladosporium sphaerospermum Penz.

Curvularia verruculosa Tandon \& Bilgrami ex M.B. Ellis

Chrysosporium merdarium

Fusarium lateritium Nees

F. solani (Mart.) Sacc.

Humicola fuscoatra Traaen

Malbranchea chrysosporioidea Sigler \& J.W. Carmich.

Myrothecium verrucaria (Alb. \& Schwein.) Ditmar

Paecilomyces farinosus (Holmsk.) A.H.S. Br. \& G. Sm.

Paecilomyces lilacinus (Thom) Samson

P. variotii Bainier

Penicillium adametzii K.M. Zalessky

P. corylophilum Dierckx

P. decumbens Thom

P. fellutanum Biourge

P. glabrum (Wehmer) Westling

P. implicatum Biourge

P. janczewskii K.M. Zalessky

$P$. janthinellum Biourge

P. lividum Westling

P. montanense M. Chr. \& Backus

P. pinophilum Thom

P. purpurescens (Sopp) Biourge

P. restrictum J.C. Gilman \& E.V. Abbott

P. solitum Westling

P. spinulosum Thom

P. verruculosum Peyronel

P. vinaceum J.C. Gilman \& E.V. Abbott

P. waksmanii K.M. Zalessky

Scolecobasidium humicola G.L. Barron \& L.V. Busch

Staphylotrichum coccosporum J.A. Mey. \& Nicot

Stilbella sebacea (Ellis \& Everh.) Seifert

Trichoderma harzianum Rifai

T. koningii Oudem.

Total of CFU

\begin{tabular}{ccccccccccccc}
0 & 0 & 0 & 0 & 0 & 0 & 1 & 0 & 0 & 0 & 0 & 0 & 1 \\
0 & 0 & 0 & 0 & 0 & 1 & 0 & 0 & 1 & 0 & 0 & 0 & 2 \\
0 & 0 & 0 & 0 & 0 & 0 & 0 & 0 & 0 & 0 & 1 & 0 & 1 \\
0 & 0 & 0 & 0 & 0 & 0 & 0 & 0 & 2 & 0 & 0 & 0 & 2 \\
0 & 0 & 8 & 0 & 0 & 0 & 0 & 0 & 0 & 0 & 0 & 0 & 8 \\
0 & 0 & 0 & 1 & 0 & 1 & 17 & 1 & 2 & 1 & 3 & 0 & 26 \\
0 & 0 & 12 & 3 & 0 & 0 & 2 & 10 & 0 & 0 & 0 & 0 & 27 \\
0 & 0 & 0 & 1 & 0 & 0 & 0 & 0 & 0 & 0 & 0 & 0 & 1 \\
0 & 0 & 9 & 0 & 6 & 0 & 0 & 0 & 1 & 0 & 0 & 0 & 16 \\
0 & 0 & 8 & 0 & 0 & 0 & 0 & 0 & 0 & 0 & 0 & 0 & 8 \\
0 & 1 & 0 & 0 & 0 & 118 & 0 & 0 & 0 & 0 & 0 & 0 & 119 \\
0 & 0 & 0 & 0 & 0 & 0 & 1 & 0 & 0 & 0 & 1 & 0 & 2 \\
0 & 0 & 0 & 0 & 0 & 0 & 98 & 0 & 0 & 0 & 8 & 0 & 106 \\
0 & 0 & 8 & 1 & 0 & 0 & 0 & 0 & 1 & 0 & 0 & 0 & 10 \\
0 & 0 & 0 & 6 & 0 & 0 & 2 & 0 & 0 & 0 & 5 & 0 & 13 \\
0 & 0 & 0 & 42 & 0 & 0 & 0 & 55 & 0 & 0 & 0 & 0 & 97 \\
0 & 0 & 0 & 0 & 0 & 2 & 0 & 0 & 0 & 0 & 0 & 0 & 2 \\
0 & 0 & 0 & 0 & 3 & 0 & 0 & 0 & 0 & 0 & 0 & 0 & 3 \\
0 & 0 & 0 & 0 & 0 & 0 & 0 & 0 & 0 & 0 & 1 & 0 & 1 \\
0 & 0 & 0 & 0 & 0 & 0 & 0 & 1 & 0 & 0 & 0 & 0 & 1 \\
0 & 0 & 0 & 1 & 0 & 0 & 0 & 2 & 0 & 0 & 0 & 0 & 3 \\
0 & 0 & 0 & 0 & 3 & 0 & 0 & 0 & 0 & 0 & 0 & 0 & 3 \\
0 & 0 & 4 & 0 & 0 & 12 & 0 & 1 & 0 & 0 & 0 & 0 & 17 \\
0 & 0 & 0 & 0 & 0 & 0 & 0 & 0 & 0 & 0 & 5 & 0 & 5 \\
0 & 1 & 0 & 0 & 7 & 0 & 13 & 1 & 1 & 0 & 19 & 0 & 42 \\
0 & 0 & 8 & 0 & 0 & 0 & 0 & 0 & 0 & 0 & 0 & 0 & 8 \\
0 & 0 & 0 & 0 & 0 & 0 & 1 & 0 & 0 & 0 & 0 & 0 & 1 \\
0 & 0 & 0 & 0 & 0 & 0 & 0 & 0 & 0 & 0 & 2 & 0 & 2 \\
0 & 0 & 0 & 37 & 3 & 0 & 0 & 0 & 0 & 0 & 2 & 0 & 42 \\
0 & 0 & 0 & 0 & 0 & 0 & 0 & 41 & 0 & 0 & 0 & 0 & 41 \\
0 & 0 & 0 & 0 & 0 & 0 & 1 & 0 & 0 & 0 & 0 & 0 & 1 \\
0 & 0 & 4 & 0 & 0 & 0 & 0 & 0 & 0 & 0 & 0 & 0 & 4 \\
0 & 2 & 0 & 0 & 0 & 0 & 0 & 0 & 0 & 0 & 0 & 0 & 2 \\
0 & 5 & 0 & 0 & 0 & 2 & 0 & 0 & 0 & 0 & 0 & 0 & 7 \\
0 & 1 & 0 & 0 & 0 & 0 & 0 & 0 & 0 & 0 & 0 & 0 & 1 \\
11 & 101 & 173 & 123 & 48 & 192 & 213 & 186 & 23 & 17 & 113 & 93 & 1293 \\
\hline
\end{tabular}

Acrophialophora levis, Chrysosporium merdarium, Curvularia verruculosa, Malbranchea chrysosporoidea, Penicillium adametzii, Staphylotrichum coccosporum and Stilbella sebacea were isolated for the first time in Brazil.

The numbers of colonies in the sub-areas IV and II differed from the sub-areas I and V, while the sub-areas III and VI did not differ of the rest of the sub-areas. There were no statistically significant differences in the total number of colonies compared between rainy and dry seasons or when the two seasons were compared within the same sub-area (Fig. 2). The test of ScottKnot showed that Paecilomyces lilacinus, Penicillium adametzii, P. fellutanum and Acremonium roseolum were distinguished in relation to $\mathrm{CFU}$.

\section{DISCUSSION}

The Caraíba Mining in northeastern Brazil is characterized by having a typical vegetation called caatinga. Caatinga consists of a dry environment with xerophitous plants. The genera isolated in the mining area are commonly present in the soil (9). Aspergillus and Penicillium were the genera with the highest number of species, 25 and 19 species respectively and were considered by Dix and Webster (8) the genera with the best ability of surviving in dry environment.

The sub-area IV (control) should the highest number of species and CFU, 33 and 399, respectively. In contrast, the subarea I, the most affected by copper mining, had the lowest 


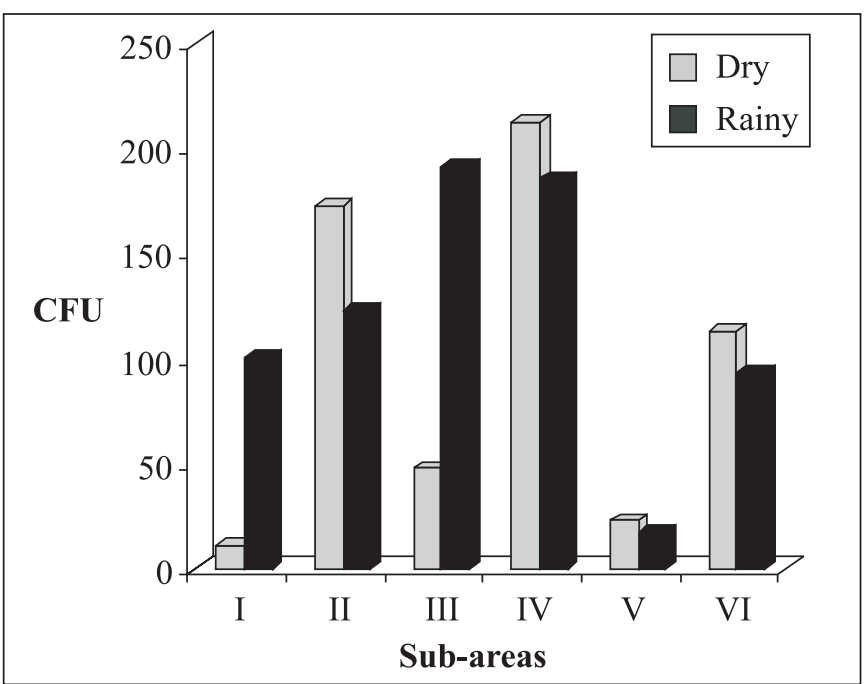

Figure 2. Differences in the number of the fungal colony forming units (CFU) between dry and rainy seasons of each studied sub-area of the Caraíba Mining, BA. Differences were not statistically significant.

number of species (10) and CFU (112). Similarly, in sub-area V, had 12 species isolated and 40 CFU and in sub-area III had 24 species and $240 \mathrm{CFU}$. The low number of species and propagules in the sub-areas I, III and V may be due to the high $\mathrm{pH}$ or high concentrations of $\mathrm{Cu}$ or Fe (Table 1). Silva et al. (22), working with AMF in the same area of the present study, also observed low number of spores in the sub-areas I and V. Nordgren et al. (17), Arnebrant et al. (3) and Durall and Parkinson (10) observed strong effects of heavy metals on the community structure of soil fungi along with reduction on biomass. Our data are in accordance with Dix and Webster (8), who reported reduced number of viable propagules in soils with high $\mathrm{pH}$. Another factor that can influence the number of colonies in soil is the plant diversity. In sub-area I (with waste product), only four species of fungi and $11 \mathrm{CFU}$ were isolated during the dry season, when no plant species were found, whereas in the rainy season seven species were isolated with $101 \mathrm{CFU}$, when some pioneer plants were found. In sub-area V (the interface), which had low numbers of colonies in the dry and rainy seasons, the plants were dried and without leaves. Dix and Webster (8) mentioned that roots and the age of the plants stimulate the growth of microorganisms when compared to soil without vegetation.

Acremonium roseolum, Stilbella sebacea and Trichoderma koningii were isolated only in sub-area I, which might indicate that these species are not good competitors but good survivors.

Aspergillus flavus, A. fumigatus, A. terreus, A. versicolor, Fusarium solani and Humicola fuscoatra isolated frequently in the mining, were also found commonly by Fassatiová (16) in a uranium mine.
Paecilomyces farinosus, presented in the Caraíba Mining with 8 CFU, was also isolated by Nordgreen et al. (17) in a brass mill where $\mathrm{Cu}$ and $\mathrm{Zn}$ were the dominant elements. The same authors observed that $P$. farinosus was more frequent with an increase in copper concentration. Arnebrant et al. (3), working with copper tolerance by microfungi, tested 22 species of Hyphomycetes isolated from polluted and unpolluted forest, and observed that $P$. farinosus was the species most copper tolerant. The authors also observed that the majority of the species of Penicillium tested were moderately copper tolerant and this included $P$. montanense and $P$. spinulosum, which were also isolated in this research. Paecilomyces lilacinus had more CFU (119), one of which in the sub-area I and 118 in sub-area III, all during the rainy season.

The species identified (Table 2) were deposited in Culture Collection (URM) of the Department of Mycology of the "Universidade Federal de Pernambuco", and may be utilized in future researches for the recuperation of mining degraded areas and in processes of bioremediation.

\section{ACKNOWLEDGEMETS}

We thank CNPq for supporting this research and also Dr. José Luis Bezerra and Dr. Tatiana Baptista Gibertoni for revision of paper, Dr. Gladstone Alves da Silva for donation of soil.

\section{RESUMO}

\section{Hyphomycetes de solo de uma área de mineração de cobre no Estado da Bahia, Brasil}

Com o objetivo de observar o impacto produzido pelas atividades da mineração de cobre em fungos do solo, amostras foram coletadas de uma área da Mineração Caraíba no Estado da Bahia, Brasil. Esta área foi dividida em seis sub-áreas: uma com vegetação nativa, usada como controle enquanto as outras variavam de acordo com os graus de impacto. As amostras, coletadas durante os períodos de estiagem e chuvoso, foram submetidas a diluições sucessivas e colocadas em placas de Petri contendo meio Sabouraud acrescido de antibiótico. Sessenta e cinco espécies e 16 gêneros de Hyphomycetes foram identificados: Acremonium, Acrophialophora, Aspergillus, Cladosporium, Chrysosporium, Curvularia, Fusarium, Humicola, Malbranchea, Myrothecium, Paecilomyces, Penicillium, Scolecobasidium, Staphilotricum, Stilbella e Trichoderma. Acrophialophora levis, Chrysosporium merdarium, Curvularia verruculosa, Malbranchea chrysosporoidea, Penicillium adametzii, Staphylotrichum coccosporum e Stilbella sebacea foram isoladas pela primeira vez no Brasil.

Palavras-chave: ecologia, área impactada, micologia, fungos de solo 


\section{REFERENCES}

1. Alexopoulos, C.J.; Mims C.W.; Blackwell, M. Introductory Mycology. John Wiley \& Sons, Inc., New York, $4^{\mathrm{a}}$ ed., 1996, 869p.

2. Allsop, D.; Seal, K.J. Introdution to biodeterioration. Edward Arnold (Publishers) Ltd. London, 1986, 132p.

3. Arnebrant, K.; Bääth, E.; Nordgren, A. Copper tolerance of microfungi isolated from polluted and unpolluted forest soil. Mycologia, 79, 890-895, 1987.

4. Barron, G.L. The genera of Hyphomycetes from soil. Robert E. Krieger Publishing Company, New York, 1972, 364p.

5. Cardoso, E.J.B.N.; Tsai, S.M.; Neves, M.C.P. Microbiologia do solo. Sociedade Brasileira de Ciência do Solo, São Paulo, 1992, 360p.

6. Carmichael, J.W.; Kendrick W.B.; Conners, I.L.; Sigler, L. Genera of Hyphomycetes. University of Alberta Press, Alberta, 1980, $386 \mathrm{p}$.

7. Clark, F.E. Agar-plate method for total microbial count. In: Black, C.A.; Evans, D.D.; White, J.L.; Ensminger, L.E.; Clark, F.E. Dinauer, R.C. (eds.): Methods of soil analysis. Part 2. Chemical and microbiological properties. Madson Inc, New York, 1965, p.14601466.

8. Dix, N.J.; Webster, J. Fungal ecology. Chapman \& Hall, London, $1995,549 \mathrm{p}$

9. Domsch, K.H.; Gams W.; Traute-Heidi, A. Compendium of soil fungi. Academic Press, New York, 1980, 859p.

10. Durall D.M.; Parkinson, D. Initial fungal community development on decomposing timothy (Phleum pratense) litter from a reclaimed coal-mine spoil in Alberta, Canada. Mycol. Res., 95, 14$18,1991$.
11. Eggins, H.O.; Allsopp, D. Biodeterioration and biodegradation by fungi. In: Smith, J.E.; Berry, D.R. (eds.). Industrial Micology. The Filamentous Fungi. Edward Arnold, London, 1975, p.301-319.

12. Ellis, M.B. Dematiaceous Hyphomycetes. Commonwealth Mycological Institute, Kew, 1971, 608p.

13. Ellis, M.B. More Dematiaceous Hyphomycetes. Commonwealth Mycological Institute, Kew, 1976, 507p.

14. EMBRAPA. Centro Nacional de Pesquisa Tecnológica em Informática para a Agricultura. SWNTIA, versão 4.2.1 Instalação e Programa Campinas. 1996.

15. EMBRAPA. Manual de métodos de análise de solo. 2 ed. EMBRAPA, Rio de Janeiro. 1997.

16. Fassatiová, O. Micromycetes inhabiting the mines of Príbram (Czechoslovakia). Ceska Mykol., 24, 162-165, 1970.

17. Nordgren, A.; Bääth, E.; Söderström, B. Soil microfungi in an area polluted by heavy metals. Can. J. Bot., 63, 448-455, 1984.

18. Paul, E.A.; Clark, F.E. Soil microbiology and biochemistry. Editora?, San Diego, 1989, página final.

19. Pitt, J.I. A laboratory guide to common Penicillium species. Commonwealth Scientific and Industrial Research Organization, Australia, 1991, 187p.

20. Raper, K.B.; Fennell, D.I. The genus Aspergillus. Robert and Krieger Publishing Company, Inc., Florida, 1977, 686p.

21. SAEG Sistema para análises estatísticas. UFV-MG. Fundação Arthur Bernardes. V 5.0. 1993

22. Silva, G.A.; Maia, L.C.; Silva, F.S.B.; Lima, P.C.F. Potencial de infectividade de fungos micorrízicos arbusculares oriundos de área de caatinga nativa e degradada por mineração, no Estado da Bahia, Brasil. Rev. Bras. Bot., 24, 135-143, 2001. 